\title{
Region's Financial Accounting Information System and the Quality of Local Government Financial Reports
}

\author{
Abdul Rahman, Zulkifli Fachri \\ Universitas Hasanuddin, Indonesia \\ unhasmediaty@gmail.com
}

\begin{abstract}
This study aimed to analyze the use of region's financial accounting information system to the quality of local government financial reports. The quality of the financial statements includes the relevance, reliable, comparable, and understandable. The dependent variable in this study is the quality of local government financial reports, while the independent variable in this study is the region's financial accounting information system. This research method is qualitative research with this type of approach theoretical studies that the methods used to collect data or resources related to the topics in a study. Data obtained from journals, thesis, books, and various other literatures related to the study. The results showed that the use of local financial information systems positive effect on the quality of local government financial reports.
\end{abstract}

Keywords: Accounting Information System, Regional Financial, Quality of Financial Reporting

\section{Introduction}

Background: Poor financial reporting from local governments in Indonesia is rampant phenomenon discussed. It is marked by the government's financial statements are still many areas that do not provide information in accordance with applicable regulations and there are many irregularities in the financial statements found by the Audit Board of the Republic of Indonesia (BPK - RI) in the audit. Based on data from the Overview Examination Semester II that of 524 LKPD government audited by BPK 157 LKPD or $30 \%$ that received unqualified opinion, 309 LKPD or $59 \%$ who obtain the qualified opinion, and the rest get a bad opinion (BPK RI, 2014).These financial statements are a tool of accountability for financial performance management of a government to the public entrusted to him (Prasetyo \& Juliaty, 2005). The financial report is a reflection to be able to know a government has been running well, so the government is required to be able to produce quality financial reports. According to the Regulation government Number 71 Year 2010 described the qualitative characteristics of financial statements of the government that is normative preconditions necessary for the financial statements of the government can meet the desired quality that is relevant, reliable, comparable and understandable.

One contributing factor in producing high quality financial statements is an accounting information system, in which the financial statements resulting from a process that is based on good input, process and output are both good. These three aspects must be integrated and sustainable as the foundation of good financial reporting systems (Slamet, 2011).The development of information technology so rapidly makes the technology as part of a support various activities, especially for government entities who expect good governance, economic, effective and efficient. In line with the expectations of the government, especially the local government to realize good governance, local governments is trying to make it happen by building information technology in the field of finance or accounting in relation to financial management. We have had many local governments use information technology in the form of software accounting or financial management applications developed both by the government such as Financial Management Information System (SIPKD) and Regional Management Information System (SIMDA) and applications developed by the private sector.

Problem Statement: Based on the background of the problem, the formulation of the problem in this research is: The use of Regional Financial Accounting Information System for Quality Government Finance Report. 
Research Purpose: The purpose of this research is to know how to use Regional Financial Accounting Information System for Quality Government Finance Report.

Research Method: This research method is qualitative research with this type of approach theoretical studies that the methods used to collect data or resources related to the topics raised in a study. Data obtained from journals, thesis, books, and various other literatures related to the study. Data collection is by direct or by direct observation is the way to collect data by using the eye without the help of another standard tool for this purpose. Data obtained and analyzed by descriptive analysis method is to describe the influence of financial accounting information system of the area with the qualitative characteristics of financial statements. The qualitative characteristics of financial statements in question are relevant, reliable, comparable and understandable.

\section{Literature Review and Discussion}

Regions Financial Accounting Information System: Accounting information systems (AIS) is a framework for coordinating the resources (data, materials, equipment, suppliers, personnel, and funds) to convert the input in the form of economic data into the output of financial information that is used to carry out the activities of an entity and to provide accounting information for party concerned (Wilkinson, 2000). The purpose of accounting information system is to provide the information required in decision making activities carried out by the so-called information processing. Most of the output required by the information processing is provided by the transaction processing system, such as the financial statements of a transaction processing system. In general, Management Information System (MIS) is a system that can assist management in data collection, processing and analysis of data evaluation and present to the limits of valuable information and finally came to the decision where this information is useful to support the functions of management operations (Machmud, 2013)

The area of financial accounting information system is a system of grouping, recording, and processing of financial activities of local governments into a financial statement as information that can be used by certain parties in decision-making. With advances in information technology are evolving so rapidly and the potential for widespread utilization, the management of, and access to financial information areas can be carried out more quickly and accurately. In the government accounting system, there are some important characteristics or the necessary requirements, including that the government accounting system must be designed in accordance with the constitution and the laws in force in a country. Government accounting system must be able to provide information that can be accounted for and audited. Government accounting system must be able to provide the financial information necessary for preparation of plans / programs and the evaluation of physical and financial execution (Gunadi et al., 2002). In the preparation and financial management, we need a system that regulates the process of classification, measurement, and disclosure of all financial transactions, called the accounting system. To produce financial information that is useful for the users, the financial statements should be prepared by personnel who have competence in the field of financial management and accounting system (Tuasikal, 2007).It is also that by applying Accounting Information Systems effectively, it can provide the information received to assist management decisions in question. Accounting Information Systems Effectiveness can be evaluated as value-added benefits. Effectiveness of Accounting Information Systems is a measure of success to meet the goals set. The successful implementation of SIA can be interpreted profitable application, a major concern of the organization, to give satisfaction to many users and improve the quality of their performance (Moscoveet et al., 2009).

Financial management starting from planning, budgeting income and expenditure (APBD), financial administration to accounting and reporting. Financial administration system applications good area should include all phases of financial management so that there is continuity of processes and data. The continuity of the process and the data input process will eliminate repeated data from one stage to the next so as to reduce the volume of work and improve the consistency and quality of data because there will be no errors in the process of rein putting the data (Kusrini and AndriKoniyo, 2007). In the explanation of the Government Regulation No. 56 of 2005 that has been updated to Government Regulation No. 65 Year 2010 on Regional Financial Information System mentioned that in order to follow up the implementation of the development process in line with the principles of good governance ( good governance ), local governments are obliged to 
develop and exploit advances in information technology to improve financial management, and deliver financial information to public service as a form of accountability for the activities carried out by the Government.

Qualitative Characteristics of Financial Statements: The qualitative characteristics of financial statements in accordance with Government Regulation No. 71 of 2010 concerning Government Accounting Standards (SAP) are normative measures that need to be realized in the accounting information so that it can fulfill its purpose. The following four characteristics is a prerequisite normative necessary in order to meet the government's financial statements desired quality:

Relevant: Financial statements can be said to be relevant if the information contained therein may affect decisions by helping them evaluate the events of the past or the present, and predict the future, and confirm or correct the results of their evaluations in the past. Accordingly, the financial statements of the relevant information can be linked to the intended use. Information can be said to be relevant if it fulfills the conditions which have the benefit of feedback, have the benefits of predictive, timely and complete. So that relevant information can be presented, the information presented in the financial statements of the government should be based on the information needs of users of financial statements of the government.

Reliably: The information in the financial statements is free from errors and misleading understanding of material, presenting any facts in an honest and verifiable. Information may be relevant, but if the nature or presentation of unreliable then use that information could potentially misleading and detrimental to the financial statements. The information reliably meets the characteristics of that presentation honest, verifiable, and neutrality. So that the information produced reliable (reliably), the presentation of information in the financial statements of the government should be based on the legislation in force, and presented thoroughly.

Can Be Compared: Users should be able to compare the financial statements of entities between periods to identify trends in financial position and performance and to compare the financial statements to evaluate an entity's financial position, performance and changes in relative terms. Therefore, measurement and presentation of financial effects of transactions and other similar events done consistently. Information contained in the financial statements would be more useful if it can be compared to the prior year financial statements or other reporting entity's financial statements in general. Comparison can be done internally and externally. Internal comparisons can be made when an entity apply the same accounting policy from year to year

Can Be Understood: The information presented in the financial statements can be understood if the government said users understand the information presented and is able to interpret it. It can be seen from the benefits of the information presented to decision making. To that end, the presentations of information in financial statements the government should use the format/form and terms that are tailored to the understanding of the users. Users must be assumed to have sufficient knowledge of the activities and the reporting entity's operating environment and a willingness to study the information presented in the financial statements of the government.

\section{Empirical Review}

Several studies on the application of accounting information systems at the local government is Indriasari (2008), Harifan (2009) and Yosefrinaldi (2013), found no evidence that suggests that a significant difference between the use of information technology to the quality of financial reports of local government and its relationship positive. Research Fikri (2011) states that the area of financial supervision SIKD and positive significant effect on the quality of financial statements. Delanno (2013) showed that a significant difference between the use of information technology to the value of the local government financial reporting information and positive relationship. The influence of the use of information technology to the value of the local government financial reporting information is the greater use of information technology, the value of financial reporting information generated will be the better government. Ratifah (2012) showed that the area of financial accounting systems have a significant impact on the quality of financial statements. 
Winidyaningrum study (2010) showed that in addition to human resource capacity, the quality of local government financial statements are also affected by the use of information technology.

In line with Government Regulation No. 56 Year 2005 concerning Regional Financial Information System that is in line with research conducted by Nurlaela and Rahmawati (2010) with the title of the Organization Keprilakuan Effect Uses Regional Financial Information System . The result is that with the application of financial accounting system is a good area then it will have an impact on the quality of financial reports good area anyway. Halens (2014) in his research entitled Analysis System Implementation Management Information Region (SIMDA) tehadap Quality Financial Statements on education shows that the use of SIMDA has been mandated by the legislation in force, but the level of user participation SIMDA still low which will affect the quality of the financial statements. Correspondingly, Diana (2005), finding the obstacles facing local government in order to implement financial accounting system area of the cash-based to cash a modified accrual, including: the weakness of human resources who understand the accounting in the financial section, require long duration of time (transition) whenever there is a change in the system from the old system to the new system, the slow pace of preparation of regional regulations with respect to changes in the system, the selection of an alternative model of the accounting system of the Indonesian Institute of Accountants based International Public Sector Accounting Standards (IPSAS) that use accrual basis accounting system of governments using a modified cash basis.

\section{Conclusion}

Based on the study of theory and to analyze the results of previous studies, the researchers in this case can be concluded that the use of Financial Accounting Information Systems area affects the quality of local government financial reports. If use of Financial Accounting Information Systems dearah operated properly it will create a better quality of financial reporting as well and vice versa. One of the success factors so that an accounting information system can be a positive influence on the quality of financial statements that human resources be user in the application of the system. Level of competence, participation will be strongly supported in order to realize the effectiveness of the use of the Financial Accounting Information System.

Recommendation: Based on the above conclusions, some suggestions can be given that:

- To each government, in order to obtain good quality financial statements, the accounting information system already owned in order to be implemented effectively, especially pay attention to the quality of human resources that support the effectiveness of the implementation of the system.

- Limitations researchers here are only limited to the study of theory without taking into account the primary data field such as direct observation and interviews with the object of study; it is suggested further research to conduct field research.

\section{References}

Badan Pemeriksa Keuangan. (2014). Results of Audit Financial Statements Second Half of 2014. Jakarta

Delanno, G. D. (2013). Effects of Human Resource Capacity, Utilization of IT and Comptroller against Financial Reporting Information Value of Local Government. Journal of WRA, 1(1).

Diana, T. I. (2005). Towards Implementation of Regional Financial Accounting System New. Executive Journal, $2(2)$.

Fikri, M. (2011). Effect of SIKD and Regional Financial Supervision on the Quality of Financial Statements (Empirical Study in Padang city government SKPD). Essay. Faculty of Economics, University of Padang.

Ryanlie, H. (2014). Analysis of Regional Management Information System Implementation (SIMDA) on the Quality of Financial Statements SKPD (A Case Study of Southeast Minahasa Regency PPKAD Office). Samratulangi University.

Harifan, H. (2009). Effect of Human Resource Capacity, Utilization of Information Technology and Accounting Internal Control for Financial Reporting Information Value of Local Government in SKPD government of Padang. Essay, Faculty of Economics, University of Padang. 
Indriasari, D. (2008). The Effect of Human Resource Capacity, Utilization of Information Technology and Internal Control System of Financial Reporting Information Value of Local Government. SNA Journal. Palembang: Politeknik Negeri Sriwijaya.

Kusrini \& AndriKoniyo. (2007). Practical demands Developing Accounting Information Systems. Yogyakarta: ANDI Yogyakarta

Machmud, R. (2013). Relationship Management Information Systems and Services with Employee Performance at Rutan Makassar. Jurnal Capacity STIE AMKOP Makassar, 9(1), 78-85

Moscove, S. M., Simkin, \& Bagnaroff. (2009). Core concept of Accounting Information System. Newyork, NY, John Wiley \& Sons.Inc

Nurlaela, S. \& Rahmawati. (2010). Effect of Organizational Behavioral Factors The usefulness of the Regional Financial Accounting System in Subosukawonosraten. Journal SNA, 8(2).

Prasetyo, D. \& Juliaty, R. (2005). Financial Statement Analysis Concepts and Applications 2nd Edition. Yogyakarta: UPP AMP YKN

Ratifah, I. (2012). Moderating Influence of Organizational Commitment Regional Financial Accounting System on the Quality of Financial Statements. Fakultas Ekonomi Universitas Pasundan. Bandung.

Gunadi, R., Loho, S. \& Sugianto. (2002). Accounting for Government and Non - Profit Organizations. Malamg: PPAK Universitas Brawijaya Malang.

Slamet, K. (2011). BPK Give Opinion WDP against LKPD Six District Government/Cities Jabar. Press Release Submission LHP - LKPD 2010. July 2011. Bandung.

Tuasikal, A. (2007). Understanding the influence of Accounting System, Financial Management Performance against Local Government Unit (Studies in Central Maluku district in Maluku Province). Journal of Accounting and Finance Public Sector, 08(01), 1466-148

Wilkinson, J. W. (2000). Accounting Information Systems 4th edition. New York: John Wiley \& Son.

Winidyaningrum. (2010). Effect of HR and IT Utilization Against Countability and timeliness of Local Government Financial Reporting By intervening variable Internal Control Accounting.

Yosefrinaldi. (2013). Effect of Human Resources Capacity and Utilization of Information Technology on the Quality of Government Finance Report with an intervening variable Government Internal Control System (Empirical Studies in the Department of Finance and Asset Management Se West Sumatra). Program Studi Akuntansi Fakultas Ekonomi Universitas Negeri Padang. 